\title{
Complimentary Digital Sources Challenging Noida (NCR youth) for Acceptability with Internet Marketing:- A Multi Dichotomy Analysis
}

\author{
Effulgence \\ Vol. 16 No. 1 (Special Issue 2) \\ January - June, 2018 \\ Rukmini Devi Institute of Advanced Studies \\ E-mail : effulgence@rdias.ac.in, Website : www.rdias.ac.in \\ http://effulgence.rdias.ac.in/user/default.aspx \\ https://dx.doi.org/10.33601/effulgence.rdias/v16/iSpl2/2018/27-31
}

\section{Dr. Gurvishal Sinha ${ }^{1}$}

\begin{abstract}
This paper suggests analytical understanding about Noida youth with complimentary digital sources in internet marketing. Research converges to attain a focus point for complimentary medias, which is most assessed and commonized by youth in Noida. Convergences highlight the proven advantages, to corporate through multi dichotomy analysis for assigning digital media strategy for sustainable and profit-maximizing internet marketing.
\end{abstract}

Keywords: complementary media, multi dichotomy analysis, youth, Internet marketing.

\section{INTRODUCTION}

Whe marketing model of the system is
"translated" into the technical model by the transition mechanism of two elements of the proposed value model - the design principles and the marketing decisions to be taken by managers during the design process (Ivanov, 2008).Every business works on model whether it is a traditional brick and mortar or vis use of internet technology in 21 st century. The web offers companies' ownership and control of all interactions with customers and thus creates both the ability and the need to improve their overall experience (Srivastava, 2012). As per research, $90 \%$ of online shoppers are planning to buy more products online which reflect on the positive experience of the users (Mishra,2016).According to digital strategy consulting online, activities for college students in statistical data format is as follows use of email $31 \%$, chat $(19 \%)$, information $(35 \%)$, entertainment $(13 \%)$, e-commerce $(2 \%)$. Young men email $(54 \%)$, chat $(12 \%)$, information $(16 \%)$, entertainment (11\%), e-commerce (7\%). College students when growing old with age and habits and moves as a youth in different walks of life with earning, living parameters and consumption changes. This is reflected in e-commerce usage by youth a drastic upward shift in e-commerce usage. Direct technologies are available but some indirect technologies we are taking into account in this research paper that is mobile, SMS, internet radios, digital television.

\section{Sharda University}




\section{LITERATURE REVIEW}

The mobile phone has become dominant as a personal device for communication and commerce. The mobile wireless Internet service refers to mobile service activities including mobile telecommunication, mobile content, entertainment service and mobile commerce on a mobile platform(Wan, \& Cormier, 2010). As a result, the dynamics of the retail experience is evolving, and investing in digital technology is becoming an important strategic imperative for many retail brands today(Yasav, 2015). SMS. Offering an incentive appears to be successful since the purchase intention is higher when a benefit can be gained by receiving an SMS ad. Also, the advertisement's appeal is of influence(Roozen \& Genin 2008). Along with the growth of mobile telephony, the use of wireless data services specifically Short Message Service (SMS) - has also grown exponentially. The growth of mobile services has been even more spectacular in some of the less developed countries in Africa, Asia, and Europe(Kim, et.al. 2009). In India, post the year of 1992, when cable Television business started flourishing in Indian television market, television viewers were also looking for more entertainment options apart from state-owned broadcaster Doordarshan (DD). During that time with the launch of Zee TV and Star TV through the spread of cable TV, Indian marketers got more space and frequency on television to advertise their products (Sharma \& Gupta., 2015).According to www.watconsultant.com 162 minutes on smartphones, 96 minutes on television. 95 minutes on laptops,31 minutes on a tablet in India people are viewing advertisements. India is going to be no exception with the influx of Smart TVs. In the future, this will allow markets to programmatically reach consumers on a TV screen at scale with little or no spillover. In Play theory, it is told that people use media for getting entertainment rather than getting information and education (Sen,2017). According to Statista.com The ad market in India is forecast to increase by 2.84 billion U.S. dollars between 2015 and 2018; this is the fifth largest ad expenditure growth in the world during this time period. According to exchange4media their report suggests, with $94 \%$ Bangalore exhibited the highest acceptance to the medium, tier 2 cities like Jaipur $(89 \%)$ and Lucknow (82\%) were also not far behind in reiterating the national acceptance of the medium. Interestingly, the South of the country seems to be more content driven, while the rest of the regions were more music driven. The literature review provides enough evidence that Indian society is now traveling with internet spectrum and cheering acceptability for internet marketing. The literature review also guides that for complimentary digital medias less empirical work was present.

\section{IMPORTANCE OF RESEARCH}

This research highlights what other digital medias are having their active presence in the mind of Noida (NCR)youth, as they are most affected by digital gadgets and technologically savvy social thrusts.

\section{RESEARCH METHODOLOGY:-}

\author{
Research design: exploratory design \\ Sampling Element- Youth(15-24) \\ Sample size:- 100
}

Research tool:- Interviewing face to face( Focused interview) and checklist to assign ticks give data sheet.

Kind of data:- primary and secondary

Collection procedure:- computer sheet for recording the preferences (electronic data feeding), one to one discussion was conducted with every element.

Control measures:- Noise control measures are advised. Free hours of elements are checked and suitable time is selected with an element for information retrieval No consultation is allowed by element for controlling the biases in response. Unwillingness error is closely monitored if found that was removed in data collection process. 
Experimental time:- one week (1 hour per day)

Experimental instrument:- scale used 1=preffered, $0=$ notpreffered, $5=$ missing value(it is used so that if the respondent does not reach any conclusion for other media sources then this option is given to utilize.). It does not mean that research data has a missing value.

Statistical method:-Multi dichotomy analysis is an analysis which is having two sets of response, it is a type of multiple response analysis. When more than one answer may be selected by the respondents, the response for a single observation can be classified into more than one category. The problem of multiple response variables can be observed and studied inn-way contingency tables (LAVASSANI, et.al, 2009).

\section{DATA ANALYSIS AND INTERPRETATION:-}

\begin{tabular}{|c|c|c|c|c|c|c|}
\hline \multicolumn{7}{|c|}{ Case Summary } \\
\hline & \multicolumn{6}{|c|}{ Cases } \\
\hline & \multicolumn{2}{|c|}{ Valid } & \multicolumn{2}{|c|}{ Missing } & \multicolumn{2}{|c|}{ Total } \\
\hline & $\mathrm{N}$ & Percent & $\mathrm{N}$ & Percent & $\mathrm{N}$ & Percent \\
\hline \$othermedia ${ }^{a}$ & 99 & $99.0 \%$ & 1 & $1.0 \%$ & 100 & $100.0 \%$ \\
\hline
\end{tabular}

Above table reflects $99 \%$ presence of valid data, that is overall frequencies for choices drawn in experimental collection procedure. This missing value is not missing value but this $1 \%$ frequencies are the new innovative outcome of research. These are new extent about youth's perception for not considering the other complementary media as a source of internet marketing.

Findings:- new wave of the market is available for complimentary media as a source of attraction for internet marketing which is yet not properly pitched.
Corporate expediency: - Internet marketing organization can tap this $1 \%$ stratum of youth in a variety of ways, virtual assistance for suggesting on products and services through complementary medias is a better way because on mobile phones 24 by 7 connectivity, SMS links of videos for short visual demonstration are a most advantageous feature in mobile-based communications. Loyalty schemes must be introduced in combination with bonus point strategy for usage and further followup and purchase.The main idea behind this strategy is to give a compulsive focus for adjusting with complementary medias for future internet marketing.

\begin{tabular}{|c|c|c|c|c|}
\hline \multicolumn{5}{|c|}{ Sothermedia Frequencies } \\
\hline & & \multicolumn{2}{|c|}{ Responses } & \multirow{2}{*}{$\begin{array}{c}\text { Percent } \\
\text { of } \\
\text { Cases }\end{array}$} \\
\hline & & $\mathbf{N}$ & Percent & \\
\hline \multirow[t]{4}{*}{ marketingtechnologies ${ }^{a}$} & MOBILE PHONES & 77 & $30.0 \%$ & $77.8 \%$ \\
\hline & SMS & 54 & $21.0 \%$ & $54.5 \%$ \\
\hline & INTERNET RADIO & 68 & $26.5 \%$ & $68.7 \%$ \\
\hline & DIGITALTELEVISION & 58 & $22.6 \%$ & $58.6 \%$ \\
\hline \multicolumn{2}{|l|}{ Total } & 257 & $100.0 \%$ & $259.6 \%$ \\
\hline
\end{tabular}

a. Dichotomy group tabulated at value 1 . 
1. Mobile phones are preferred by youth as their first choice for internet marketing(77.8\%), discussion with youth suggests that usage of mobile phone is on maximum utility for them. Mobile phones are most interactive and communicationally handy device for youth more than any other gadget of today's technology.

2. Internet Radio is trajecting at second place with $(68.7 \%)$, discussion points highlight about listening different internet radio station gives relaxation, increase in moods and decrease in stress mechanism. A feature of listening continuity emerges that provides a space for short internet marketing activities.

3. Digital television is storing third place with $(58.6 \%)$, discussion concludes television viewing is not much relaxing because sitting straight in front of the television after hectic day does not solve the relaxation issues with viewing but mobile provides the same.

4. SMS are the on the fourth choice of youth holding(54.5\%), discussion identifies that reading is a though activity due to the huge traffic of messages every day. Still, they read due to a feature of mobile communication and obsession of checking the SMS. So youth treat as a boring activity.

\section{OUTCOMES OF RESEARCH}

Research guides two frameworks active and passive orientations in attitude for accepting any media. Active orientation suggests fast, handy, and relaxing attitude for medias which enhances these features. Passive orientations highlights features that hinder relaxation and additionally requires external pressure to go with complimentary media are less preffered.

\section{SUGGESTIONS}

Today's Media is not at all the traditional media; it should portray viability for acceptance in a variety of forms. Companies of virtual marketing and
Physical marketing must understand the flexibility, focus, features, and functionality effects for marketing with youth.

\section{LIMITATIONS}

This research does not highlight other groups of society, it provides a specific segmentation based research and focused outcome.

\section{REFERENCES}

1. Ivanov, Stanislav Hristov, Conceptual Marketing Framework for Online Hotel Reservation System Design (November 5, 2008). Tourism Today, Vol. 8/2008, pp. 7-32.Available SSRN: https://ssrn.com/ abstract $=1296040$ or http:/ /dx.doi.org/10.2139/ssrn.1296040

2. Srivastava, Rajshree, Shift of Marketing Mix to E-Marketing Mix: The Birth to New Era (January 27, 2012). Available at SSRN: https:/ / ssrn.com/abstract=1992936 or http://dx.doi.org/10.2139/ssrn.1992936.

3. Mishra, P(2016)." CAN MONEY BUY CONVENIENCE: A STUDY ON INCOME AS A MOTIVATOR OF ONLINE SHOPPING?", Management\&Marketing, volume XIV, issue $1 / 2016$.

4. Lee, Jung Wan and Cormier, James, Effects of Customers' Demographic Profile on Mobile Commerce Adoption (April 30, 2010). Journal of Distribution Science, Vol. 8, No. 1, pp. 5-11, 2010. Available at SSRN: https:// ssrn.com/abstract $=3089147$

5. Chaffey, D., Chadwick Ellis, F., Johnson, K., Mayer, R . Internet marketing strategy, implementation and practice, Third Edition, Pearson Education.2003.

6. Yasav, Sue, The Impact of Digital Technology on Consumer Purchase Behavior (November 7, 2015). Journal of Financial Perspectives, Vol. 3, No. 3, 2015. Available at SSRN: https:/ /ssrn.com/abstract=3084041.

7. Roozen, I. \& Genin, E. (2008)." Can we compare SMS marketing to Traditional Marketing 
Communications?", HUB RESEARCH PAPER 2008/50. OKTOBER 2008.

8. Kim, Youngsoo, and Telang, Rahul and Vogt, William B. and Krishnan, Ramayya, Empirical Analysis of Mobile Voice and SMS Service: A Structural Model (April 1, 2009). Available at SSRN: https://ssrn.com/abstract $=1085285$ or http://dx.doi.org/10.2139/ssrn.1085285.

9. Sharma, Pooja and Gupta, Priya, Semiotic Analysis of Indian Television Advertisements and its Impact on Consumers: An Exploratory Study (Analyse Sémiotique De Télévision Indienne: Publicité Et Son Impact Sur Les Consommateurs: Une Étude Exploratoire ) (July 23, 2015). SHARMA, Pooja and GUPTA, Priya, Semiotic Analysis of Indian Television Advertisements and its Impact on Consumers: An Exploratory Study, ESSACHESS - Journal for Communication Studies, Vol. 8, No 1(15), 2015. Available at SSRN: https:// ssrn.com/abstract $=2644257$.

10. https:/ / www.watconsult.com/2017/08/ digital-will-overtake-tv-viewership-india-2020/

11. Sen. S(2017), "Changing Trend of Product Advertising: A Study on Cadbury Dairy Milk", Journal of Content, Community \& Communication Amity School of Communication Vol. 5 Year 3, June - 2017 [ISSN: 2395-7514 (Print).

12. https://www.statista.com/topics/2116/ advertising-industry-in-india/

13. http:// www.exchange4media.com/Radio/Over-64-population-in-India-listens-to-FMRadio-every-day--AZ-Research-report_ 65436.html.

14. LAVASSANI, M, K., MOVAHEDI, B. \& Kumar, V. (2009), "Developments in the analysis of multiple response survey data in categorical data analysis: the case of enterprise system implementation in large North American firms", Journal of applied quantitative methods" VOL.4, NO.1, Spring, 2009. 